\title{
NGHIÊN CỨU TÍNH KHÁNG KHÁNG SINH CỦA VI KHUẨN GÂY VIÊM PHỔI Ở TRẺ 2 THÁNG ĐẾN 5 TUỔI TẠI BỆNH VIỆN SẢN NHI NGHỆ AN NĂM 2021
}

\section{TÓM TẮT}

Mục tiêu: Mô tả tình hình kháng kháng sinh của vi khuẩn trong điều trị Viêm phổi ở trẻ 2 tháng đến 5 tuổi tại Bệnh viện Sản nhi Nghệ An năm 2021. Phương pháp nghiên cứu: Nghiên cứu tiến cứu, mô tả loạt ca bệnh. Kết quả: Nghiên cứu cho thấy trẻ em ở nhóm 2-12 tháng tuổi có tỷ lể mắc Viêm phổi cao nhất (65,5\%). Tỷ lệ nam /nữ: 1.8/1.0. Viêm phổi nặng chiếm $82,2 \%$ tông số trẻ nhập viện; Tỷ lệ sử dụng kháng sinh trước khi nhập viện là 51,1 .Tỷ lệ tự ý sứ dụng kháng sinh tại nhà khi trẻ bị viêm phổi còn cao $(17,8 \%)$. Kết quả nuôi cấy cho thấy tỷ lệ gây bệnh chư yếu nhóm vi khuẩn Gram (-) H.influenzae là $73,3 \%$, nhóm Vi khuẩn Gram (+) là S.pneumoniae là $26,7 \%$. H.Influenzae đề kháng cao với nhóm Ampicillin, Ampicillin-Sulbactam, Amoxicilin-Acid Clavulanic lần lượt là 98,5\%, 95,5\%, 78,8\%. Tỷ lệ đề kháng với Cefuroxime, Cefotaxime, Ceftazidime, Ceftriaxone lần lượt là 97\%, 33,3\%, 22,7\%, 21,2\%. Azithromycin tỷ lệ là 75,8\%. Đã ghi nhận đề kháng Imipenem với tỳ lệ $3 \%$. S.Pneumoniae có tỷ lệ để kháng cao $100 \%$ với Azithromycin, Erythromycin, Clarithromycin. Tiếp đến là Tetracyclin với 79,2\%. Tý lệ đề kháng với Cefotaxime, Ceftriaxone, Chloramphenicol lân lượt là $45,8 \%, 41,7 \%, 12,5 \%$. Kết luận: Tính kháng kháng sinh của vi khuẩn đối với một số nhóm kháng sinh phổ rộng ngày càng cao. Sử dụng thuốc kháng sinh không hợp lý và lạm dụng thuốc kháng sinh làm tăng tỷ lệ kháng kháng sinh của vi khuẩn gây bênh.

Tư khóa: Viêm phổi, Tính kháng kháng sinh, Kháng sinh

\section{SUMMARY}

RESEARCH ON ANTIBIOTIC RESISTANCE OF PNEUMINITIS - CAUSING BACTERIA IN 2 MONTHS TO 5 YEARS OLD CHILDREN AT NGHE AN CHILRDREN'S HOSPITAL IN 2021

Objective: To describe the situation of antibiotic resistance of bacteria in the treatment of pneumonia in children 2 months to 5 years old at Nghe An Obstetrics and Pediatrics Hospital in 2021. Methods: Prospective, descriptive case series. Results: The study showed that children in the 2-12 month age group had the highest incidence of Pneumonia (65.5\%). Male/Female Ratio: 1.8/1.0. Severe pneumonia accounted for $82.2 \%$ of the total number of hospitalized children; The rate of antibiotic use

${ }^{1}$ Trường Đại hoc Y khoa Vinh

Chịu trách nhiệm chính: Trần Thị Kiều Anh

Email: bacckieuanh@gmail.com

Ngày nhận bài: 2.8.2021

Ngày phản biên khoa học: 30.9.2021

Ngày duyệt bài: 6.10 .2021

\section{Trần Thị Kiều Anh ${ }^{1}$, Nguyễn Văn Tuấn ${ }^{1}$}

before hospitalization was 51.1 . The rate of selfadministering antibiotics at home when children had pneumonia was still high (17.8\%). The culture results showed that the pathogenic rate of Gram (-) H.influenzae group was $73.3 \%$, the Gram (+) group was S.pneumoniae was $26.7 \%$. H.Influenzae is highly resistant to Ampicillin, Ampicillin-Sulbactam, Amoxicillin-Clavulanic Acid groups, respectively 98.5\%, $95.5 \%, 78.8 \%$. The rate of resistance to Cefuroxime, Cefotaxime, Ceftazidime, Ceftriaxone was 97\%, $33.3 \%, 22.7 \%, 21.2 \%$, respectively. Azithromycin rate is $75.8 \%$. Imipenem resistance has been recorded with the rate of $3 \%$. S.Pneumoniae has a high rate of $100 \%$ resistance to Azithromycin, Erythromycin, and Clarithromycin. Next is Tetracycline with $79.2 \%$. The rates of resistance to Cefotaxime, Ceftriaxone, and Chloramphenicol were $45.8 \%, 41.7 \%$, and $12.5 \%$, respectively. Conclusion: The antibiotic resistance of bacteria to some groups of broad-spectrum antibiotics is increasing. Improper use of antibiotics and overuse of antibiotics increase the rate of antibiotic resistance of pathogenic bacteria.

Keywords: Pneumonia, Antibiotic resistance, Antibiotic

\section{I. ĐẶT VẤN ĐỀ}

Viêm phổi là bệnh thường gặp ở trẻ em, là nguyên nhân chính gây bệnh tật và tử vong cho trẻ em dưới 5 tuổi. Tổ chức $Y$ tế thế giới xếp Việt Nam ở vị trí thứ 9 trong nhóm 15 quốc gia có gánh nặng bệnh tật Viêm phổi trẻ em cao nhất. Nghiên cứu tại Bệnh viện nhi trung ương trên trẻ bị Viêm phổi do vi khuẩn trong 5 năm từ 20062010 cho thấy nguyên nhân do vi khuẩn gram (+) là $31,6 \%$, trong đó S. pneumoniae $12,7 \%$, vi khuẩn gram (-) là $68,4 \%$ trong đó $\mathrm{H}$. Influenza $12,1 \%$. Vấn đề kháng kháng sinh ở Việt Nam ngày càng trở nên trầm trọng, xuất hiện vi khuẩn kháng với nhiều loại kháng sinh. Sự kháng thuốc kháng sinh xét về bản chất là do việc sử dụng kháng sinh không đúng gây ra. Kháng kháng sinh trở thành vấn đề cấp thiết của toàn cầu.

Bệnh viện Sản Nhi Nghệ An là bệnh viện tuyến đầu khu vực Bắc miền Trung có số trẻ chẩn đoán Viêm phổi và điều trị nội trú trung bình 150-200/ ngày. Yêu câuu đặt ra lúc này là phải lựa chọn thuốc kháng sinh đáp ứng được hiệu quả điều trị, an toàn, kinh tế và giảm thiểu được sự đề kháng kháng sinh của vi khuẩn. Do đó, chúng tôi tiển hành thực hiện đề tài này nhằm mục tiêu: Khảo sát thực trạng kháng kháng sinh của vi khuẩn trong điều trị Viêm phổi 
ở trẻ 2 tháng đến 5 tuổi tại Bệnh viện Sản nhi Nghệ An năm 2021.

\section{II. ĐỐI TƯƠ'NG VÀ PHƯƠNG PHÁP NGHIÊN CỨU}

1. Đối tượng nghiên cứu: 90 trẻ từ 2 tháng đến 5 tuổi được chẩn đoán Viêm phổi điều trị tại Khoa Hô hấp - Bệnh viện Sản Nhi Nghệ An.

1.1. Tiêu chuân lựa chon: Trẻ từ 2 tháng đến dưới 5 tuổi được chẩn đoán Viêm phổi theo tiêu chuẩn Bộ Y Tế 2015.

1.2. Tiêu chuẩn loại trừ: Mắc các bệnh nhiễm trùng khác ngoài phổi, suy giảm miễn dịch,..., không đồng ý tham gia nghiên cứu.

\section{Phương pháp nghiên cứu}

2.1. Địa điểm và thời gian nghiên cứu: Địa điểm nghiên cứu: Khoa Hô hấp, Bệnh viện Sản nhi Nghệ An; Thời gian nghiên cứu: Từ 01/2021 đến 06/2021.

2.2. Thiết kế nghiên cứu: Nghiên cứu tiến cứu, mô tả loạt ca bệnh.

2.3. Cỡ mẫu và phương pháp chọn mẫu

- Cỡ mẫu: 90 bệnh nhân

- Phương pháp chọn mẫu: Chọn mẫu thuận tiện, lựa chọn tất cả bệnh nhân đáp ứng tiều chuẩn lựa chọn và tiêu chuẩn loại trừ trong thời gian nghiên cứu.

2.4. Các tiêu chuẩn áp dụng trong nghiên cứu: Tiêu chuẩn chẩn đoán Viêm phổi: Chẩn đoán Viêm phổi theo tiêu chuẩn Bộ Y Tế 2015.

2.5. Phương pháp xử lý số liệu: Số liệu xử lý bằng phần mềm SPSS 26.0. Sử dụng test $x 2$ để so sánh sự khác biệt về tỷ lệ phần trăm. Sự khác biệt có ý nghĩa thống kê khi $\mathrm{p}<0,05$.

\section{KẾT QUẢ NGHIÊN CỨU}

3.1. Đặc điểm đối tượng nghiên cứu - Phân bố tuổi và giới

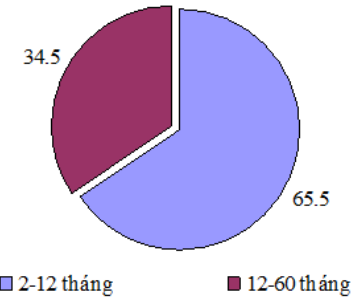

Biểu đồ 3.1: Phân bố theo tuổi

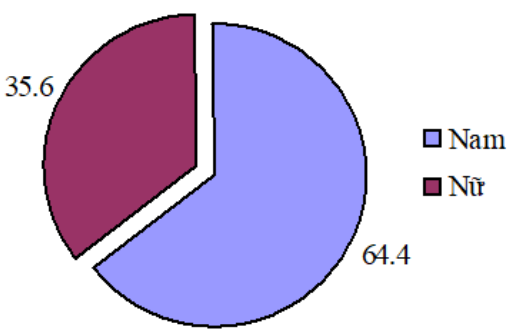

Biểu đồ 3.2: Phân bố theo giới tính

Nhận xét: Trẻ có độ tuổi 2-12 tháng có tỉ lệ mắc Viêm phổi là $65,5 \%$ so với nhóm tuổi 12 tháng-60 tháng là 34,5\%. Tỷ lệ nam /nữ: 1.8/1.0.

- Phân bố theo tuổi, mức độ nặng viêm phổi

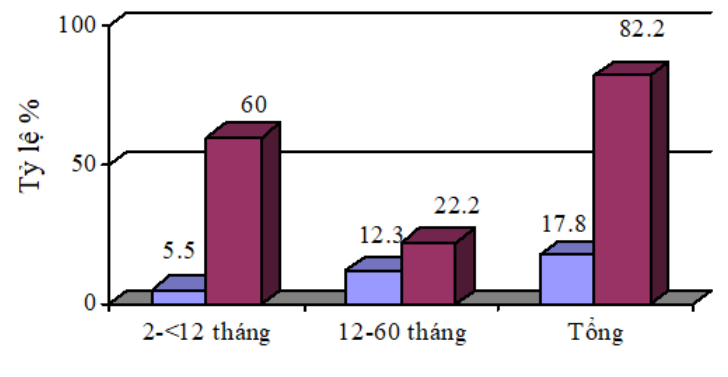

Viêm phổi $\square$ Viêm phổi nặng

Biểu 3.3: Phân bố theo tuổi, mức độ năng

Nhận xét: Tỷ lệ trẻ bị Viêm phổi nặng chiếm $82,2 \%$ cao hơn nhiều so với số bệnh nhân nhóm Viêm phổi $17,8 \%(p=0,001)$.

- Sử dụng kháng sinh trước khi vào viện

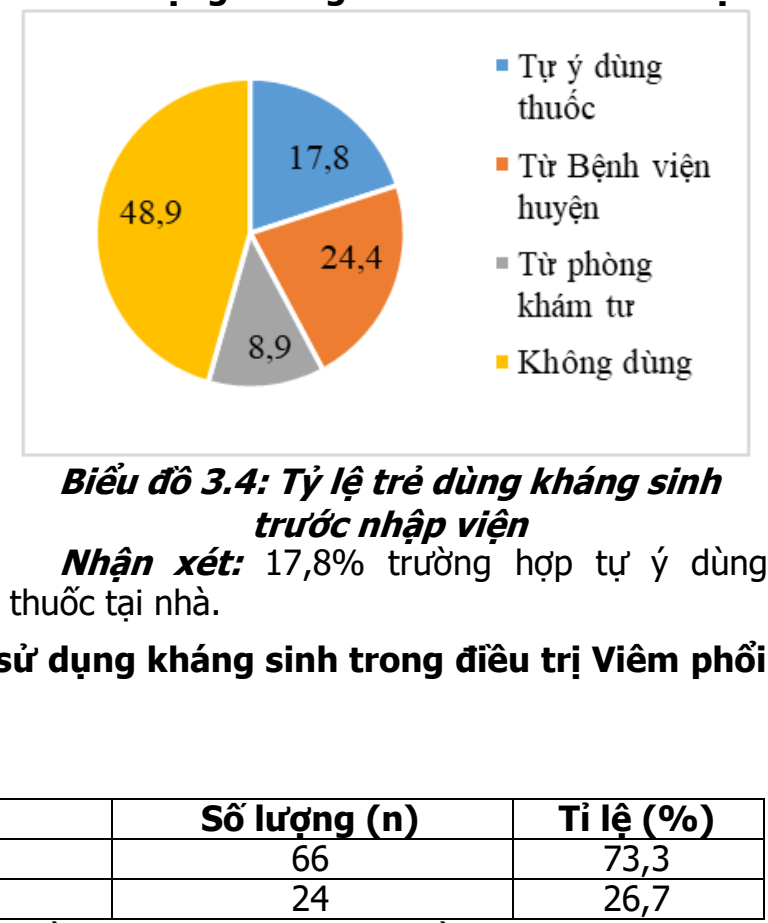

3.2. Nhóm vi khuẩn gây bệnh và tình hình sử dụng kháng sinh trong điêu trị Viêm phổi ở trẻ 2 tháng đến 5 tuổi.

- Kết quả nuôi cấy vi khuẩn

Bảng 3.1: Kết quả nuôi cấy vi khuẩn

\begin{tabular}{|c|c|c|c|}
\hline \multicolumn{2}{|c|}{ Vi khuấn } & Số lượng (n) & Tỉ lệ (\%) \\
\hline Gram(-) & H.influenzae & 66 & 73,3 \\
\hline Gram (+) & S.pneumoniae & 24 & 26,7 \\
\hline
\end{tabular}

Nhận xét: Kết quả nuôi cấy vi khuấn H.influenzae là 73,3\%, S.pneumoniae là 26,7\%. 
- Tình hình kháng kháng sinh của vi khuẩn H.influenzae.

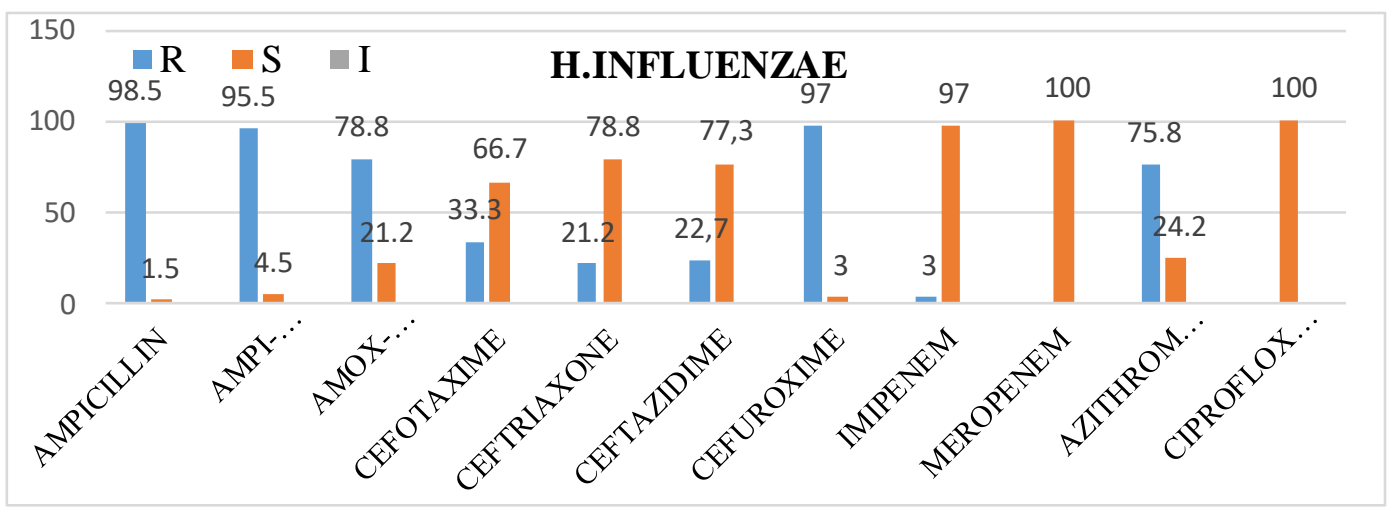

Biểu đồ 3.5: Tỉ lệ kháng kháng sinh của vi khuẩn H.influenzae

Nhận xét: H.influenzae có tỷ lệ kháng với kháng sinh Ampicillin, Ampicillin-Sulbactam, Amoxicilin-Acid Clavulanic, Azithromycin tỷ lệ lần lượt là 98,5\%, 95,5\%, 78,8\%, 75,8\%. Đã ghi nhận đề kháng Imipenem với tỷ lê $3 \%$.

- Tình hình kháng kháng sinh của vi khuẩn S.pneumoniae.

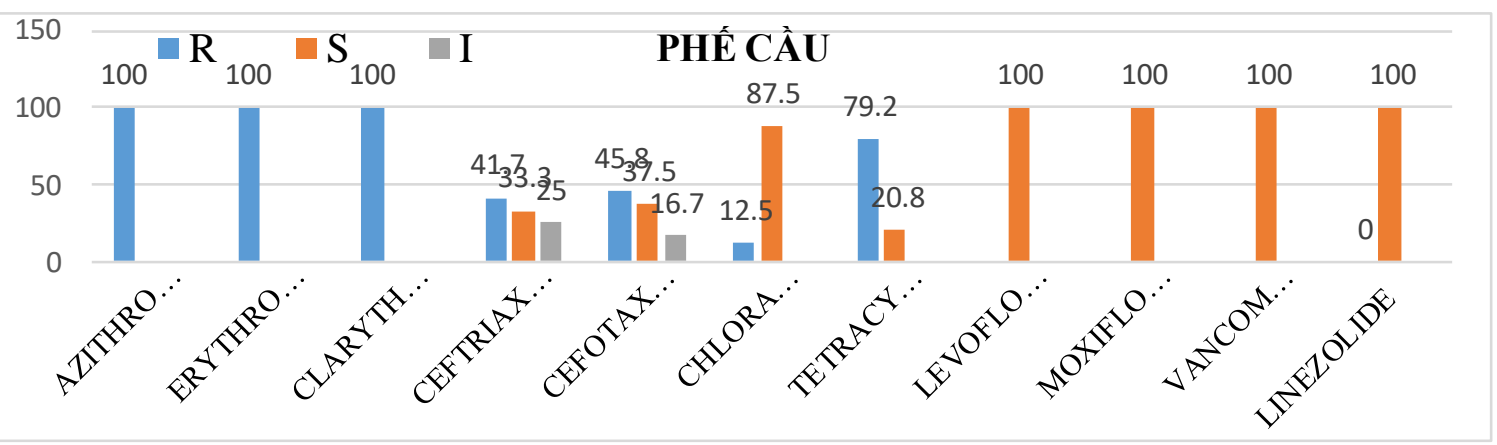

Biêu đồ 3.6. Tỉ lệ kháng kháng sinh của vỉ khuẩn S.pneumoniae

Nhận xét: Tỷ lệ $100 \%$ kháng kháng sinh của vi khuẩn S.pneumoniae với Azithromycin, Erythromycin, Clarithromycin. 100\% đáp ứng với Levofloxacin, Moxifloxacin, Vancomycin, Linezolide.

- Phù hợp trong điêuu trị kháng sinh sau khi có kết quả kháng sinh đồ

Bảng 3.2: Phù hợp trong đîêu trị kháng sinh sau khi có kết quả kháng sinh đồ

\begin{tabular}{|c|c|c|c|c|c|c|}
\hline \multirow{3}{*}{$\begin{array}{c}\text { Mức độ Viêm } \\
\text { phổi }\end{array}$} & \multirow{2}{*}{\multicolumn{2}{|c|}{ Đối kháng sinh }} & \multirow{2}{*}{\multicolumn{2}{|c|}{ Không đổi KS }} & \multirow{2}{*}{\multicolumn{2}{|c|}{ Tống }} \\
\hline & & & & & & \\
\hline & $\begin{array}{l}\text { Số lượng } \\
\text { (n) }\end{array}$ & $\begin{array}{l}\text { Tỷ lệ } \\
(\%)\end{array}$ & $\begin{array}{c}\text { Số lượng } \\
\text { (n) }\end{array}$ & $\begin{array}{l}\text { Tỷ lề } \\
(\%)\end{array}$ & $\begin{array}{l}\text { Số lượng } \\
\text { (n) }\end{array}$ & $\begin{array}{l}\text { Tỷ lề } \\
(\%)\end{array}$ \\
\hline Viêm phổi & 11 & 12.2 & 5 & 5,6 & 16 & 17,8 \\
\hline VP nặng & 29 & 32,2 & 45 & 50,0 & 74 & 82,2 \\
\hline Tống & 40 & 44,4 & 50 & 55,6 & 90 & 100 \\
\hline$p$ & \multicolumn{2}{|c|}{$\mathrm{p}<0,05$} & \multicolumn{2}{|c|}{$\mathrm{p}<0,05$} & \multicolumn{2}{|c|}{$\mathrm{p}<0,05$} \\
\hline
\end{tabular}

Nhận xét: $44,4 \%$ bênh nhân phải thay đổi kháng sinh sau khi có kết quả kháng kháng sinh đồ trong đó nhóm Viêm phổi nặng là 32,2\%. Sự khác biệt có ý nghĩa thống kê với $p<0,05$.

- Kết quả điều trị

Bảng 3.3: Kết quả điều trị

\begin{tabular}{|c|c|c|c|c|c|c|}
\hline \multirow[b]{2}{*}{ Kết quả điêu trị } & \multicolumn{2}{|c|}{ Viếm phối } & \multicolumn{2}{|c|}{ Viêm phối nặng } & \multicolumn{2}{|c|}{ Tống } \\
\hline & $\begin{array}{c}\text { Số lượng } \\
\text { (n) }\end{array}$ & $\begin{array}{l}\text { Tỷ lệ } \\
(\%)\end{array}$ & $\begin{array}{l}\text { Số lượng } \\
\text { (n) }\end{array}$ & $\begin{array}{l}\text { Tỷ lệ } \\
(\%)\end{array}$ & $\begin{array}{l}\text { Số lượng } \\
\text { (n) }\end{array}$ & $\begin{array}{l}\text { Tỷ lề } \\
(\%)\end{array}$ \\
\hline Khỏi & 15 & 93,8 & 63 & 85,1 & 78 & 86,7 \\
\hline Không thay đối & 1 & 6,2 & 11 & 14,9 & 12 & 13,3 \\
\hline Tống & 16 & 100 & 74 & 100 & 90 & 100 \\
\hline
\end{tabular}

Nhận xét: Kết quả điều trị có tỷ lệ khỏi là 86,7\%, 13,3\% bệnh giảm chậm hoặc có xu hướng nặng lên. 
- Thời gian điêuu trị

Bảng 3.4: Thời gian điều tri

\begin{tabular}{|c|c|c|c|c|c|}
\hline $\begin{array}{c}\text { Mức độ viêm } \\
\text { phối }\end{array}$ & Số lượng & $\begin{array}{l}\text { Nhỏ nhất } \\
\text { (ngày) }\end{array}$ & $\begin{array}{l}\text { Lớn nhất } \\
\text { (ngày) }\end{array}$ & $\begin{array}{c}\text { Trung bình } \\
\text { (ngày) }\end{array}$ & $\begin{array}{l}\text { Đố lệch } \\
\text { chuẩn }\end{array}$ \\
\hline Viềm phối & 16 & 5 & 15 & 8,0 & 2,6 \\
\hline VP nặng & 74 & 3 & 19 & 8,7 & 2,8 \\
\hline
\end{tabular}

Nhận xét: Thời gian điều trị của các bệnh nhi trung bình là $8,6 \pm 2,8$ ngày.

\section{BÀN LUÂN}

90 trẻ được chọn vào nghiên cứu, tỷ lệ mắc bệnh Viêm phổi nam /nữ là 1.8/1.0; Trong đó độ tuổi 2-12 tháng có tỉ lệ mắc là $65,5 \%$ so với nhóm tuổi 12 tháng - 60 tháng là 34,5\%. Kết quả này cho thấy có mối liên quan giữa tỷ lệ mắc bệnh và khả năng đề kháng của trẻ, trẻ càng nhỏ thì sức đề kháng của trẻ càng yếu, hệ thống miễn dịch chưa hoàn thiện trong khi trẻ phải tiếp xúc với môi trường sống có rất nhiều yểu tố gây bệnh và đôi khi không được trong sạch, bị ô nhiễm. Theo nghiên cứu của Trần Thị Anh Thơ [1] tỷ lệ bị viêm phổi ở nam $63,75 \%$ lớn hơn ở nữ $36,25 \%$, độ tuổi mắc bệnh cao nhất là 2-12 tháng tuổi $65,63 \%$ sau đó giảm dần theo chiều tăng lứa tuổi, từ 48-60 tháng chiếm tỷ lệ thấp nhất 2,5\% [2].

- Nghiên cứu của chúng tôi cho thây tỷ lệ trẻ mắc Viêm phổi nă̆ng giảm dần theo chiều tăng của lứa tuổi cụ thể số trẻ thuộc nhóm Viêm phổi nặng chiếm $82,2 \%$ cao hơn nhiêu so với số trẻ nhóm Viêm phổi 17,8\%; Trẻ mắc Viêm phổi nặng giảm dần theo lứa tuổi với tỷ lệ Viêm phổi nặng ở độ tuổi 2-12 tháng là $65,5 \%$ giảm xuống 34,5\% ở độ tuổi 12- 60 tháng. Sự khác biệt có ý nghĩa thống kê với $p<0,05$, cho thấy mối liên quan giữa độ tuổi và mức độ bệnh.

- Kết quả nuôi cấy vi khuẩn: Phân lập được vi khuẩn tại Khoa Hô Hấp Bệnh viện Sản Nhi Nghệ An cho thấy căn nguyên chiếm tỷ lệ cao nhất là H.influenzae $(73,3 \%)$, tiếp đến là S.pneumoniae $(26,7 \%)$. Nghiên cứu cho kết quả khá tương đồng so với nghiên cứu của tác giả Nathan [7] với tỷ lệ vi khuẩn $\mathrm{H}$.influenzae chiếm đa số $29,3 \%$, tiếp sau đó tỷ lệ S.aureus, S.pneumonia tương ứng là $24,0 \%, 22,7 \%$. Nguyên nhân vi khuẩn ở các nghiên cứu có sự khác biệt, có thể do căn nguyên thường gặp ở từng vùng địa lý là khác nhau. Môi trường sống, khí hậu, chủng tộc ở mỗi quốc gia có thể thuận lợi cho các loại vì khuẩn khác nhau phát triển và gây bệnh viêm phổi ở trẻ em.

- Tỉ lệ kháng kháng sinh của H.influenzae

Kết quả nghiên cứu của chúng tôi cho thấy H.Influenzae tỷ lệ đề kháng cao với Ampicillin, Ampicillin-Sulbactam, Amoxicilin-Acid Clavulanic,
Azithromycin tỷ lệ lần lượt là $98,5 \%, 95,5 \%$, $78,8 \%, 75,8 \%$. Tương đồng với nghiên cứu của Dương Thị Hồng Ngọc tỷ lệ đề kháng tương ứng là $95,8 \%, 91,7 \%, 95,8 \%, 54,2 \%$ [2]. Nghiên cứu của Nguyễn Thị Ngọc Điệp $\mathrm{H}$. influenzae đề kháng cao với Ampicillin, Azithromycin lần lượt là $77,3 \%$ và $87,2 \%$ [3].

Tỷ lê đề kháng với Cefuroxim là $97 \%$ cao hơn so với nghiên cứu của Nguyễn Thị Ngọc Điệp là 74,5\%[4]. Tỷ lệ đề kháng với Cefotaxime, Ceftazidime, Ceftriaxone lần lượt là 33,3\%, $22,7 \%, 21,2 \%$ thấp hơn so với nghiên cứu của Dương Thị Hồng Ngọc tương ứng là 95,8\%, $95,8 \%, 93,8 \%$ [2]. Nghiên cứu của chúng tôi ghi nhận H.Influenzae đề kháng kháng sinh Imipenem với tỷ lệ 3\%.

- Tỉ lệ kháng kháng sinh của S.Pneumoniae

Kết quả nghiên cứu cho thãy với S.Pneumoniae có tỷ lệ đề kháng cao $100 \%$ với Azithromycin, Erythromycin, Clarithromycin. Kết quả tương đồng với các nghiên cứu của Dương Thị Hồng Ngọc [2], Nguyển Thị Ngọc Điệp [3] Phạm Nhật Văn [4], với tỷ lệ đề kháng Erythromycin lần lượt là 98,6\%, 97,1\%, 94,9\%, nghiên cứu SOAR giai đoạn 2009-2011 cũng cho thấy tỷ lệ S.Pneumoniae kháng Macrolid là $>95 \%$. So sánh với nghiên cứu của Dương Thi Hồng Ngọc [2] tỷ lệ đề kháng với Cefotaxime, Ceftriaxone trong nghiên cứu của chúng tôi cao hơn lần lượt là $45,8 \%$ và $41,7 \%$ so với $41,7 \%$ và $29,2 \%$. Trong nghiên cứu của chúng tôi S.Pneumoniae còn nhạy cảm hoàn toàn với Levofloxacin và Moxifloxacin, Vancomycin, Linezolid. Sự đề kháng với kháng sinh đường uống như Azithromycin rất cao do việc sử dụng kháng sinh không hợp lý, tự ý cho trẻ uống kháng sinh khi không có chỉ định của bác sĩ.

Kết quả điều trị: $86,7 \%$ bệnh nhân được điều trị khỏi bệnh, 13,3\% bệnh nhân không khỏi phải chuyển khoa hoặc chuyển viện. Kết quả nghiên cứu tương đồng với nghiên cứu của Phạm Anh Tuấn tỷ lệ khỏi là 92,9\% [6], nghiên cứu của Nguyễn Thị Kim Loan tỷ lệ khỏi là 72,5\% [5].

Thời gian nằm viện: tăng theo mức độ nặng của bệnh. Có 12 trường hợp nặng chuyển khoa hoặc chuyển viện giữa đợt điều trị. Cụ thể 
thời gian nằm và thời gian sử dụng kháng sinh của bệnh nhân Viêm phổi dao động từ 3 đến 19 ngày. Thời gian điều trị Viêm phổi tại bệnh viện của các bệnh nhi trung bình là $8,6 \pm 2,8$ ngày. Kết quả nghiên cứu tương đồng với nghiên của Nguyễn Thị Kim Loan thời gian trung bình của đợt điều trị là $7,48 \pm 0,62$ ngày [5].

\section{KẾT LUẦN}

Tỷ lệ tự ý sử dụng kháng sinh tại nhà khi trẻ bị viêm phổi còn cao (17,8\%). Sử dụng kháng sinh trong cộng đồng, trước khi nhập viện là một trong các nguyên nhân dẫn đến tình trạng lạm dụng thuốc và kháng thuốc kháng sinh trong điều tri.

Kết quả nuôi cấy cho thấy tỷ lệ gây bệnh chủ yếu nhóm vi khuẩn Gram (-) H.influenzae là $73,3 \%$, nhóm Vi khuẩn Gram $(+)$ là S.pneumoniae là $26,7 \%$.

H.Influenzae đề kháng cao với nhóm Ampicillin, Ampicillin-Sulbactam, Amoxicilin-Acid Clavulanic lần lượt là 98,5\%,95,5\%, 78,8\%. Tỷ lệ đề kháng với Cefuroxime, Cefotaxime, Ceftazidime, Ceftriaxone lần lượt là 97\%, 33,3\%, $22,7 \%, 21,2 \%$. Azithromycin tỳ lệ là $75,8 \%$. Đã ghi nhận đề kháng Imipenem với tỷ lệ 3\%.

S.Pneumoniae có tỷ lệ đề kháng cao $100 \%$ với Azithromycin, Erythromycin, Clarithromycin.
Tiếp đến là Tetracyclin với 79,2\%. Tỷ lệ đề kháng với Cefotaxime, Ceftriaxone, Chloramphenicol lần lượt là 45,8\%, 41,7\%, 12,5\%.

\section{TÀI LIẸU THAM KHẢO}

1. Trân Thị Anh Thơ (2014), "Đánh giá tình hình sử dụng kháng sinh trong điêuu trị Viêm phổi ở trẻ em từ 2 tháng đến 5 tuổi tại bệnh viện sản nhi Nghệ $A n^{\prime \prime}$.

2. Dương Thị Hồng Ngọc (2020), "Căn nguyền và mức đô để kháng khảng sinh của vi khuân gây Viêm phổi ở trẻ em từ 2 tháng đến dưới 5 tuổi", Tap chí y hoc dự phòng tháng 6/2020.

3. Nguyến Thị Ngọc Điệp (2016), "Đặc điểm lâm săng, cận lầm sàng của Viêm phổi do vi khuẩn và tính nhạy cảm với kháng sinh của một số loại vi khuẩn gầy Viêm phổi ở trẻ em từ 2 tháng đến 5 tuổi".

4. Pham Nhật Văn (2015), "Khảo sát tình hình kháng kháng sinh và xác định các typ huyết thanh bằng kỹ thuật sinh học phân tử của các chủng Streptococcus pneumoniae xâm lấn tại khu vực phía Nam Việt Nam", Tạp chí y học dự phòng tháng $1 / 2014$.

5. Nguyễn Thị Kim Loan (2017), "Nghiên cứu tình hinh sử dụng kháng sinh trong điêu trị Viêm phổi ở trẻ em tại Bệ̂nh viện trường Đai Học Y Dược Huế".

6. Phạm Anh Tuấn (2019), "Phân tích tình hình sử duñg kháng sinh điêu trị Viêm phổi mắc phải cộng đồng cho trẻ em tại Bệnh Viện Sản Nhi Quảng Ninh"'.

7. Nathan AM, Teh CSJ, Jabar KA, Teoh BT, Tangaperumal A, Westerhout C, et al (2020), "Bacterial pneumonia and its associated factors in children from a developing country".

\section{TÌNH HÌNH NHIỄM VI KHUẨN GRAM ÂM Ở BÊNH NHÂN MỚI VÀO KHOA HỒI SỨC TÍCH CỰC BỆNH VIÊ̂N BACH MAI NĂM 2020-2021}

\section{TÓM TẮT}

Nghiên cứu mô tả cắt ngang trên 168 bệnh nhân vào điều trị tại khoa Hồi sức tích cực - Bênh viện Bạch Mai trong vòng 48 giờ từ $01 / 8 / 2020$ đến $31 / 8 / 2021$ nhằm mô tả đặc điểm nhiễm vi khuẩn của bệnh nhân. Kết quả: Tỷ lệ nhiếm vi khuẩn gram âm đa kháng ở bệnh nhân mới vào khoa Hồi sức tích cực chiếm tỷ lệ cao trên $40 \%$; đặc biệt tỷ lệ vi khuẩn gram âm đả kháng cao hơn ở những bệnh nhân chuyển từ các khoa/trung tâm khác trong bênh viện chiếm $56,16 \%$ và tữ các bệnh viện khác chiếm $69,62 \%$ so với nhóm bệnh nhân từ cộng đồng chiếm 43,75\%; có sự khác biệt về tỷ lệ nhiễm vi khuẩn ở nhóm bệnh nhân từ

\footnotetext{
${ }^{1}$ Bệnh viện đa khoa Sóc Sơn

${ }^{2}$ Trường Đại học Y Hà Nội

Chịu trách nhiệm chính: Vũ Tuấn Dũng

Email: dr.vutuandung@gmail.com

Ngày nhận bài: 3.8.2021

Ngày phản biện khoa học: 30.9.2021

Ngày duyệt bài: 7.10.2021
}

Vũ Tuấn Dũng ${ }^{1}$ Đặng Quốc Tuấn ${ }^{2}$

cộng đồng và nhóm bệnh nhân chuyển từ bệnh viện khác $(p<0,05)$. 99,4\% số bệnh nhân có điểm SOF́A lớn hơn hoăc bằng 2. Kết luận: Những $B N$ đã có nhiễm khuẩn ở thời điểm vào khoa HSTC BVBM đều có tình trang năng. Đa số BN từ nơi khác chuyển đến có nhiễm vi khuẩn Gram âm đa kháng. Nhóm bệnh nhân nhiễm khuẩn cộng đồng cũng có hơn $40 \%$ niniềm VK Gram âm đa kháng.

Tì̛ khóa: Vi khuẩn gram âm, vi khuẩn gram âm đa kháng, khoa hồi sức tích cực

\section{SUMMARY \\ CURRENT STATUS OF GRAM NEGATIVE BACTERIAL INFECTION IN PATIENTS NEWLY ADMITTED TO THE INTENSIVE CARE UNIT OF BACH MAI HOSPITAL IN 2020-2021}

A cross-sectional descriptive study on 168 patients admitted to the ICU - Bach Mai Hospital within 48 hours from August 1, 2020 to August 31, 2021 to describe the patient's bacterial infection characteristics. Results: The rate of infection with multi-resistant gram-negative bacteria in patients 